\title{
The Perceptions, Motivations, and Attitudes of English Undergraduate Students Regarding the Use of Social Media
}

\author{
Bagus Yuda Prawira1 ${ }^{*}$, Ni Made Ratminingsih², Ni Luh Putu Sri Adnyani ${ }^{3}$ \\ 1,2,3 Post Graduate Study Program, Universitas Pendidikan Ganesha, Singaraja, Indonesia
}

\section{A R T I C L E I N F O \\ Article history: \\ Received June 21, 2021 \\ Revised June 22, 2021 \\ Accepted October 30, 2021 \\ Available online December 25, 2021}

Kata Kunci:

Survei, Sosial Media, Persepsi,

Motivasi, Sikap

Keywords:

Survey, social media, Perception Motivation, Attitude

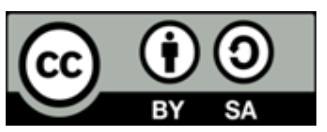

This is an open access article under the CC BY-SA license.

Copyright () 2021 by Author. Published by Universitas Pendidikan Ganesha.

\begin{abstract}
A B S T R A K
Akhir-akhir ini pemanfaatan media sosial di kalangan mahasiswa semakin menonjol. Sebagian besar studi tentang fenomena ini menyarankan agar wawasan yang diperbarui lebih lanjut diperlukan untuk mengumpulkan informasi penting. Berkaitan dengan hal tersebut, karena mahasiswa S1 Bahasa Inggris dikenal sebagai pengguna media sosial, maka perlu dilakukan kajian tentang bagaimana mereka memanfaatkan media sosial. Penelitian ini merupakan penelitian deskriptif kuantitatif yang menggambarkan persepsi, motivasi, dan sikap mahasiswa S1 Bahasa Inggris terhadap penggunaan media sosial. Melibatkan 186 peserta, penelitian ini menggunakan pertanyaan tertutup untuk mendapatkan informasi. Data dianalisis secara statistik dengan menggunakan konversi Interval. Hasil penelitian menunjukkan bahwa (1) sebagian besar mahasiswa S1 Bahasa Inggris memiliki persepsi positif terhadap penggunaan media sosial dalam dua domain: kegunaan dan kemudahan yang dirasakan, (2) terdapat lima motivasi dalam menggunakan media sosial yaitu hiburan, utilitas pribadi, pencarian informasi, kenyamanan, dan altruisme, (3) siswa menunjukkan sikap positif terhadap penggunaan media sosial karena memungkinkan mereka berkomunikasi dengan profesor dan rekanrekan mereka dengan sukses. Kesimpulannya, hasil penelitian menunjukkan bahwa penggunaan media sosial memiliki peran dalam memengaruhi persepsi, motivasi, dan sikap mahasiswa S1 Bahasa Inggris terhadap proses belajar mereka.
\end{abstract}

\section{A B S T R A C T}

Recently, the utilization of social media among higher students has become increasingly prominent. Most studies regarding this phenomenon suggested that its updated insights are further required for gathering essential information. In this regard, as English undergraduate students are known as social media users thus, a study on how they utilize social media needs to be conducted. This study is a descriptive quantitative study describing the perception, motivation, and attitude of English undergraduate students towards social media usage. Involving 186 participants, this study employed close-ended questions to obtain the information. The data were analyzed statistically by using Interval conversion. The findings shows that (1) the majority of English undergraduate students had positive perceptions toward the use of social media in two domains: perceived usefulness and ease, (2) there are five motivations in using social media namely entertainment, personal utility, information seeking, convenience, and altruism, (3) the students shows positive attitude towards the use of social media since it enables them to communicate with their professors and peers successfully. To sum up, the result of the research shows that the social media usage has a role to impact English undergraduate students' perception, motivation, and attitude toward their learning process.

\section{INTRODUCTION}

For learners, technology becomes a component of the learning process. Numerous sophisticated technologies have emerged as tools or apps that allow learners to collaboratively create, generate, and contribute knowledge in the areas of information exchange, exploration, and ideas (Sumuer, 2018). 
Furthermore, digital media technology plays an increasingly crucial part in teenage people's friendship and identity development, as well as online peer communication (Davis, 2012). Meanwhile, social networking has become a common international trend that has spread to practically every corner of the globe, and the internet is growing increasingly influential (Kaya \& Bicen, 2016; Wu, 2015). As a result of technological advancements, the internet has evolved into a digital network that connects individuals all over the world. The term "social media" refers to a set of internet-based software that can be used to create social networking sites, social bookmarking, sharing tools, social citation tools, blogging and microblogging tools, virtual worlds, e-conferencing presentations, audio and video tools, e-project management tools, and research and writing with collaboration tools (Kaplan \& Haenlein, 2010; Lee et al., 2016; Nwangwa et al., 2014; Selwyn and Stirling, 2016). As known that social media is a social network in which the medium has a role in the education system. The applications give instructional materials and learning management systems to students, especially those in higher education, using social media for interactive sharing of information with personal networks (Memmi, 2015). Several studies reported that social media as a part of technology in their learning process in which it seems to furnish an efficient media to gather insights within interactive opportunities to increase the students' potential (Dabbagh and Kitsantas, 2012; Dhanya, 2016; Talaue et al.,2018; Mushtaq and Benraghda, 2018). A study under education services company of Babson Survey Research Group and Pearson Learning Solution found that social media used by higher education in the learning process has grown 21\% from 2012 to 2013 in the United States (Seaman \& Tinti-Kane, 2013). A study also reported that social media had penetrated the lives of many young adults, the social media usage of American adults aged 18- 29 years soared from 12\% to 90\% (Perrin, 2015).

The development of social networks has commonly been used by many institutions through social media usage for the learning management system (Al-Deen \& Hendricks, 2011; Sloan \& Quan-Haase, 2017). In terms of application, the researcher expands the understanding of the use of technology in academic achievement, particularly in the use of social media in English teaching programs. Furthermore, the researcher may employ these findings to guide future researchers in collecting data on social media for similar studies. Technology has the effect of raising student attention and involvement in order to promote information transmission (Yaros, 2012). In this sense, social media has evolved into a technology with a wide range of online activities. Social media includes social networking sites, microblogs, blogs, chat platforms, open-source mapping, and photo and video sharing, among other things (Gastelum \& Whattam, 2013). To put it another way, social media offers a wide range of media applications that can clearly be used to mediate social network activities. In a more detailed context, YouTube has typically been seen as a beneficial learning resource for young learners. Studies have shown that utilizing YouTube to improve young learners' English abilities has a beneficial influence.

Social media is considered as teaching and learning tool through numerous activities, in accordance with the studies of phenomenon about social media utilization in higher students (Ariantini et al., 2021). However, several experts and researchers are still concerned about YouTube's shortcomings and risks as a learning resource for teaching English to young learners (Listiani et al., 2021). Study on other social media which focusing on higher level education such as undergraduate students is very limited. The previous findings of the studies also have called for a new study in expanding much detail about evaluations of using social media within several specific aspects. As a result, it is critical to analyze the phenomenon of social media in higher education level to explore the flaws. For this reason, this present study was worth conducted to examine and describe the utilization of social media within the learning process. The proposed study focused on describing several aspects, namely perception, motivation, and attitude of utilizing social media for their learning activities of English undergraduate students at the University of Muhammadiyah Jember. This current study offers to explore the utilization of social media by higher students in their learning activities through a survey study. The result of this study was expected to provide information regarding the use of technology in the higher education level.

\section{METHOD}

The present study was carried out using a survey method. The respondents' replies to the questionnaire were used to produce a survey. The descriptive quantitative survey was utilized to gain a comprehensive overview of the most commonly used social media by English undergraduate students, as well as their perceptions, motivations, and attitudes toward using social media for educational purposes. A "descriptive survey study" is a research method that is concerned with current events in terms of conditions, behaviours, beliefs, processes, linkages, or trends (Ary et al., 2006). This study aimed to gather information from English undergraduate students on what they think about using social media in their learning activities by reflecting on their experiences and needs as learners. For data collection, this study used a descriptive quantitative survey with closed-ended questions. The purpose of the survey was to learn 
about the perception, motivation, and attitude of English undergraduate students toward using social media. This study used a population that was easily accessible. A total of 190 English undergraduate students at the University of Muhammadiyah Jember participated in the study, with 186 English undergraduate students responding. The data in this study were obtained from the responses of English undergraduate students to a questionnaire. The researcher used a structured questionnaire with 33 items related to the research topic to collect the data. In order to complete the questionnaire, English undergraduate students should use a 5-point Likers scale to respond to the alternative responses. The researcher gathered the questionnaire responses and proceeded to examine the data. The Blueprint of the questionnaire can be seen in Table 1.

Table 1. BluePrint

\begin{tabular}{|c|c|c|c|c|c|}
\hline No & Aspect & Indicator & $\begin{array}{l}\text { Number } \\
\text { of Tests }\end{array}$ & $\begin{array}{l}\text { Number } \\
\text { of Items }\end{array}$ & Sources \\
\hline \multirow[t]{2}{*}{1} & Perception & Perceived as Usefulness & $1-5$ & 10 & (Davis, 1989) \\
\hline & & Perceived Ease & $6-10$ & & \\
\hline \multirow[t]{5}{*}{2} & Motivation & Entertainment & $11-13$ & 15 & (Al-Menayes, 2015) \\
\hline & & Personal Utility & $14-18$ & & \\
\hline & & Information Seeking & $19-20$ & & \\
\hline & & Convenience & $21-23$ & & \\
\hline & & Altruism & $24-25$ & & \\
\hline 3 & Attitude & Behavior & $26-33$ & 8 & $\begin{array}{c}\text { (Alsobrook, Wakefield } \\
\text { \& Knezek, 2011) }\end{array}$ \\
\hline
\end{tabular}

This present study used content validity and reliability. To check the validation of the instrument, the researcher did a piloting test on 30 respondents out of the selected respondents. As a result (Table 2), the Pearson product-moment $(r)$ results showed that the $r$ values (0.379-0.810) were higher than the $r$ table (0.344). Hence, it means that the questionnaire items were valid to be used. Besides, the researcher also assessed the reliability of the instrument. The Cronbach Alpha coefficient was applied to test the reliability of the instrument. The Cronbach's alpha values of the questionnaires were 0.661-0.928. Thus, it can be identified that both reliability results are categorized as reliable if the Cronbach's Alpha value is more than 0.60 (Cohen et al., 2011). The information were gathered by a questionnaire, which was tabulated and measured using a frequent basic percentage. The goal of the study was to discover more about the students' perceptions, motivations, and attitudes toward using social media for educational purposes. After that, all of the research findings were presented in a descriptive manner. Finally, the theme was used to examine the questionnaire. SPSS version 23 was used to calculate descriptive statistics (minimum, maximum, mean, range, and standard deviation) of English undergraduate students' perception, motivation, and attitude about using social media for learning activities. The researcher used interval conversion to divide the perception, motivation and attitude of English undergraduate students toward social media use into three measures. The formula is written following Azwar (2012). The participants of the survey were informed by instruction on Google form about the context, the problem area, and English undergraduate students as subjects for the study in this study. The questions were sent through the Google form into the survey approach, and then they were asked to participate with their satisfaction. The identity and the privacy of participants were promised to be kept anonymous. Current research consists of two research phases in which the data were described using SPSS 23 and supported by theoretical and empirical review. To reflect the relevant concepts of textual study and prepare a basis for final interpretations, theoretical and empirical materials helped the researcher to analyze. The theory was emerged as the result of the research both from collected data sets and analyzed data.

\section{RESULT AND DISCUSSION}

\section{Result}

For many students in today's society, learning English has become an interesting subject. Regardless, undergraduate students' use of social media has a significant impact on their ability to improve their language abilities throughout learning activities. The study's findings indicated the perception, motivation, and attitude toward using social media, as well as the most common social media use among English undergraduate students, based on the study's objectives. The information was gathered via a Google Form Link that was distributed to 186 English undergraduate students at Muhammadiyah 
Jember University. The result shows the perception, motivation, and attitude of the students towards the use of social media as follows.

The English Undergraduate Students' Perception of Utilizing Social Media for Learning Activities.

Perceptions of English undergraduate students are divided into two categories: perceived usefulness and perceived ease. The descriptive statistics of English undergraduate students' perceptions of social media use at the University of Muhammadiyah Jember. Shows the statistics result of students' perception towards the use of social media. The most students (125 students) perceived a positive belief towards the use of social media with the total percentage of $67.2 \%$. The two categories were obtained towards the benefits of social media as can be seen in Table 2. Shows that that the questionnaire had a minimum score of 23 and a maximum score of 50. The total attitude mean score was 38.98 (SD=3.87). As a result, the English undergraduate students at the University of Muhammadiyah Jember showed a good perception of social media use. The two categories were obtained: perceived usefulness and perceived ease.

Table 2. Descriptive Statistics Result of Perception

\begin{tabular}{lccccc}
\hline \multicolumn{1}{c}{ Category } & N & Min & Max & Mean & $\begin{array}{c}\text { Std. } \\
\text { Deviation }\end{array}$ \\
\hline Perceived as usefulness & 186 & 2.40 & 5.00 & 3.80 & 0.44 \\
Perceived ease & 186 & 2.20 & 5.00 & 3.99 & 0.44 \\
Overall Perception & 186 & 23.00 & 50.00 & 38.98 & 3.87 \\
\hline
\end{tabular}

The English Undergraduate Students' Motivation of Utilizing Social Media for Learning Activities.

The statistics show thorough information about the motivation of English undergraduate students at the University of Muhammadiyah Jember in using social media. The results analysis indicated that with a score of $35-55,144$ or $77.4 \%$, English undergraduate students had a score in the moderate category. According to the result score, $77.4 \%$ of English undergraduate students at the University of Muhammadiyah Jember had a moderate motivation to use social media. There were several reasons that motivate them as can be seen in Table 3. Shows the statistics result of motivation behind the use of social media for student's learning. İt was identified that there were five reasons that motivate students to use social media namely entertainment, personal utility, information seeking, convenience, and alturism. Entertainment (SD=0.47) becomes the most motivated aspect that underlie the use of social media for students. However, Alturism $(\mathrm{SD}=0.89)$ becomes the least motivated aspect that underlie the use of social media for students.

Table 3. Descriptive Statistics Result of Motivation

\begin{tabular}{lccccc}
\hline \multicolumn{1}{c}{ Category } & N & Minimum & Maximum & Mean & $\begin{array}{c}\text { Std. } \\
\text { Deviation }\end{array}$ \\
\hline Entertainment & 186 & 2.33 & 5.00 & 3.80 & 0.47 \\
Personal Utility & 186 & 2.20 & 5.00 & 3.30 & 0.68 \\
Information Seeking & 186 & 2.00 & 5.00 & 3.77 & 0.71 \\
Convenience & 186 & 2.00 & 5.00 & 3.31 & 0.64 \\
Altruism & 186 & 1.00 & 5.00 & 3.11 & 0.89 \\
Overall Motivation & 186 & 38.00 & 73.00 & 51.69 & 7.30 \\
\hline
\end{tabular}

The English Undergraduate Students' Attitude of Utilizing Social Media for Learning Activities.

The behavior domain is comprised of the attitude of English undergraduate students. The result of the analysis can shows that the overall behavior score of English undergraduate students' attitude about social media usage at the University of Muhammadiyah Jember was 29.53 within a mean score of 19-29. It can be seen that $59.7 \%$ of English undergraduate students, or 111 students, had a good attitude toward social media use. The mean score for overall behavior shows that the University of Muhammadiyah Jember's English undergraduate students have a good attitude about social media use.

\section{Discussion}

The findings revealed that English undergraduate students had a positive perception toward using social media for educational purposes. The researcher examined domain results, such as perceived as usefulness and perceived ease, in relation to the overall outcome of English undergraduate students' perception of using social media. The findings of the present study corroborated the prior studies who found 
that social media is viewed as having potential uses for learning (Alhababi et al., 2015; Odewumi et al., 2017). YouTube, Facebook, and WhatsApp were the three most popular tools for distributing materials. İt is similar to a prior study that the students obtained materials from classmates to finish their tasks using social media and vice versa (Li, 2017). İt shows that through the use of social media, the students are allowed to work collaboratively with their peers to gain information such as instructional materials in supporting their learning (Memmi, 2015; Sumuer, 2018). The social media platforms provide interactive sharing of information enable educators to give instructional materials and learning management systems to students, especially those in higher education (Memmi, 2015). The result of the present study also found that sometimes the use of social media could distract student's attention during studying. This is in line with the result of the previous research that students become addicted to social media, which bothers their attention, thereby causing a massive decrease in knowledge retention (Junco and Cotten, 2012).

Furthermore, the findings of the present study indicated that English undergraduate students were moderately motivated to use social media for learning purposes. İt was found that there were five reasons that motivate students to use social media namely entertainment, personal utility, information seeking, convenience, and alturism. The majority of English undergraduate students also believed that they utilized social media to find free information and keep up with current events. They like answering questions on social media, which they may utilize at any moment. İt supports the studies which revealed that people who use social media for knowledge, enjoyment, convenience, and personal utility are more inclined to do so (Dabbagh and Kitsantas, 2012; Dhanya, 2016; Talaue et al.,2018; Mushtaq and Benraghda, 2018). In this regard, current technology is an important component in developing strategies for fostering learning through the facilitation of collaborative learning opportunities, as well as the best approach to combine a range of factors to produce effective learning experiences for students (Heflin et al., 2017; Su \& Lai, 2021). Keeping with the social media theme, social media had become a popular educational tool (Neier and Zayer, 2015).

The final result of the analysis is the highest mean score, which describes the positive behavior. According to the English undergraduate students' assumptions, learning becomes interactive through social media, and sharing and receiving feedback from peers becomes simple. They can also efficiently communicate with their educators. This present finding supports the study by Tang et al. (2015) who revealed that social media provides a variety of social roles that can help students learn more effectively. It discusses the advantages of using social media in the classroom. For example, using Twitter for academic and co-curricular discussions has improved college students' grades (Junco et al., 2011). As a result, it showed that English undergraduate students were more likely to have an optimistic outlook. They were at ease using social media to communicate with their peers and educators, such as sharing, discussing, and looking up material. The result of the present study also found that sometimes the use of social media could distract student's attention during studying. This is in line with the result of the previous research that students become addicted to social media, which bothers their attention, thereby causing a massive decrease in knowledge retention (Junco and Cotten, 2012).

The result of this study implies that it is crucial for the English undergraduate students to realize that the utilization of the features of social media beyond the importance of the learning process might impact the negative effect on their learning achievement. The features personal utility of the entertainment side of social media may affect their learning performance which may interrupt their academic achievement. Although the result suggested that they have good perceptions and a good attitude, the utilization of social media is likely to influence their performance in the learning process. There is an opportunity for future research to explore more deeply by interviewing the stakeholder in a particular institution regarding the utilization of social toward their learning process. Although this study touched on the preferred social media used during the learning process, much more research is needed to justify this preference through the larger subject. Additionally, the descriptive survey to measure perception, motivation, and attitude of utilizing social media employed in this study is based on the instruments of the relevant previous studies that were also assumed to be reliable and valid. It can be considered as the weakness of this study. Analyzing the social media utilization in education through other methods could deliver a rich understanding with new perspectives and different insights on this subject. Therefore, a few limitations were faced in the current study that should be considered in future research.

\section{CONCLUSION}

Based on the result of the analysis, it can be concluded that the majority of English undergraduate students had positive perceptions toward the use of social media in two domains: perceived usefulness and ease. There are five motivations in using social media namely entertainment, personal utility, information seeking, convenience, and altruism. The students show positive attitude towards the use of social media 
since it enables them to communicate with their professors and peers successfully. To sum up, the result of the research shows that the social media usage has a role to impact English undergraduate students' perception, motivation, and attitude toward their learning process.

\section{REFERENCES}

Al-Deen, H. S. N., \& Hendricks, J. A. (2011). Social Media: Usage and Impact. Lexington books.

Alhababi, H., Alfadil, M., Alzamanan, M., \& Williams, M. K. (2015). Students' Perception on the Use of Social Media on Their Academic Learning. E-Learn: World Conference on E-Learning in Corporate, Government, Healthcare, and Higher 1211-1217. https: //www.learntechlib.org/p/152150/.

Ariantini, K. P., Suwastini, N. K. A., Adnyani, N. L. P. S., Dantes, G. R., \& Jayantini, I. G. A. S. R. (2021). Integrating Social Media into English Language Learning: How and to What Benefits According to Recent Studies. NOBEL: Journal of Literature and Language Teaching, 12(1), 92-111. https: //doi.org/10.15642/NOBEL.2021.12.1.91-111.

Ary, D., Jacobs, L. C., Razavieh, A., \& Sorensen, C. (2006). Introduction to Research in Education. Belmont, CA: Wadsworth.

Azwar, S. (2012). Penyusunan Skala Psikologi Edisi II. Yogyakarta: Pustaka Pelajar.

Cohen, L., Manion, L., \& Morrison, K. (2011). Planning Educational Research. Research Methods in Education. New York: Routledge Editors.

Dabbagh, N., \& Kitsantas, A. (2012). Personal Learning Environments, Social Media, and Self-Regulated Learning: A Natural Formula for Connecting Formal and Informal Learning. The Internet and Higher Education, 15(1), 3-8. https://doi.org/10.1016/j.iheduc.2011.06.002.

Davis, J. L. (2012). Social Media and Experiential Ambivalence. Future Internet, 4(4), 955-970.

Dhanya, G. (2016). Influence of Social Media on English Language Learning. Journal of English Language and Literature (JOELL), 3(1), 105-110.

Gastelum, Z. N., \& Whattam, K. M. (2013). State-of-the-Art of Social Media Analytics Research. Pacific Northwest National Lab.(PNNL), Richland, WA (United States).

Heflin, H., Shewmaker, J., \& Nguyen, J. (2017). Impact of Mobile Technology on Student Attitudes, Engagement, and Learning. Computers \& Education, 107, 91-99. https://doi.org/10.1016/j.compedu.2017.01.006.

Junco, R., \& Cotten, S. R. (2012). No A 4 U: The Relationship Between Multitasking and Academic $\begin{array}{llll}\text { Performance. Computers \& Education, } & \text { 59(2), }\end{array}$ https://doi.org/10.1016/j.compedu.2011.12.023.

Junco, R., Heiberger, G., \& Loken, E. (2011). The Effect of Twitter on College Student Engagement and Grades. Journal of Computer Assisted Learning, 27(2), 119-132. https://doi.org/10.1111/j.13652729.2010.00387.x.

Kaplan, A. M., \& Haenlein, M. (2010). Users of the World, Unite! The Challenges and Opportunities of Social Media. Business Horizons, 53(1), 59-68. https://doi.org/10.1016/j.bushor.2009.09.003 .

Kaya, T., \& Bicen, H. (2016). The Effects of Social Media on Students' Behaviors; Facebook as a Case Study. Computers in Human Behavior, 59, 374-379. https://doi.org/10.1016/j.chb.2016.02.036.

Lee, J., Kim, S., \& Ham, C.-D. (2016). A Double-Edged Sword? Predicting Consumers' Attitudes toward and Sharing Intention of Native Advertising on Social Media. American Behavioral Scientist, 60(12), 1425-1441. https://doi.org/10.1177\%2F0002764216660137.

Li, V. (2017). Social Media in English Language Teaching and Learning. International Journal of Learning and Teaching, 3(2), 148-153. https://asset-pdf.scinapse.io/prod/2624409547/2624409547.pdf.

Listiani, N. K. M., Suwastini, N. K. A., Dantes, G. R., Adnyani, N. L. P. S., \& Jayantin, I. G. A. S. R. (2021). YouTube as Digital Learning Resources for Teaching Bilingual Young Learners. 2nd International Conference on Technology and Educational Science (ICTES 2020), 156-162. https://dx.doi.org/10.2991/assehr.k.210407.230.

Memmi, D. (2015). Information Technology as Social Phenomenon. AI \& SOCIETY, 30(2), 207-214. https://doi.org/10.1007/s00146-014-0565-4.

Mushtaq, A. J., \& Benraghda, A. (2018). The Effects of Social Media on the Undergraduate Students' Academic Performances. Library Philosophy and Practice, $4(1)$. https: //core.ac.uk/download/pdf/188128705.pdf.

Neier, S., \& Zayer, L. T. (2015). Students' Perceptions and Experiences of Social Media in Higher Education. Journal of Marketing Education, 37(3), 133-143. https://doi.org/10.1177\%2F0273475315583748.

Nwangwa, K. C. K., Yonlonfoun, E., \& Omotere, T. (2014). Undergraduates and Their Use of Social Media: Assessing Influence on Research Skills. Universal Journal of Educational Research, 2(6), 446-453. 
https://eric.ed.gov/?id=EJ1053904.

Odewumi, O. M., Bamigboye, F. B., Olawuyi, O. F., \& Bamigboye, O. O. (2017). Perceptions of Undergraduate Students on Social Media for Learning: A Case Study of University of Ibadan. Journal of Communication, 8(2), 120-127. https://doi.org/10.1080/0976691X.2017.1336269.

Perrin, A. (2015). Social Media Usage. Pew Research Center, 125, 52-68.

Seaman, J., \& Tinti-Kane, H. (2013). Social Media for Teaching and Learning. Pearson Learning Systems London.

Selwyn, N., \& Stirling, E. (2016). Social Media and Education... Now the Dust has Settled. Learning, Media and Technology, 41(1), 1-5. https://doi.org/10.1080/17439884.2015.1115769.

Sloan, L., \& Quan-Haase, A. (2017). The SAGE Handbook of Social Media Research Methods. Sage.

$\mathrm{Su}$, Y.-S., \& Lai, C.-F. (2021). Applying Educational Data Mining to Explore Viewing Behaviors and Performance with Flipped Classrooms on the Social Media Platform Facebook. Frontiers in Psychology, 12. https://dx.doi.org/10.3389\%2Ffpsyg.2021.653018.

Sumuer, E. (2018). Factors Related to College Students' Self-Directed Learning with Technology. Australasian Journal of Educational Technology, 34(4). https://doi.org/10.14742/ajet.3142.

Talaue, G. M., AlSaad, A., AlRushaidan, N., AlHugail, A., \& AlFahhad, S. (2018). The Impact of Social Media on Academic Performance of Selected College Students. International Journal of Advanced Information Technology, 8(4/5), 27-35. https://doi.org/10.5121/ijait.2018.8503.

Tang, J. K. T., Yau, H.-N., Wong, S.-F., \& Wong, S.-K. (2015). The Impacts on Learning via Social Media: A Study on Post-Secondary Students in Hong Kong. International Conference on Technology in Education, 195-208. https://doi.org/10.1007/978-3-662-48978-9_19.

Wu, J.-Y. (2015). University Students' Motivated Attention and Use of Regulation Strategies on Social Media. Computers \& Education, 89, 75-90. https://doi.org/10.1016/j.compedu.2015.08.016.

Yaros, R. A. (2012). Social Media in Education: Effects of Personalization and Interactivity on Engagement and Collaboration. Social Media: Usage and Impact, 57-74. 